\title{
Environmental awareness and development of the financial market
}

\author{
Elena Semenkova ${ }^{1, *}$, and Ludmila Andrianova ${ }^{2}$ \\ ${ }^{1}$ Plekhanov Russian University of Economics, 36, Stremyanny per., 125009, Moscow, Russia \\ ${ }^{2}$ Financial University under the Government of the Russian Federation, 49, Leningradsky, 125993 , \\ Moscow, Russia
}

\begin{abstract}
The relevance of the paper is caused by the need to find new channels to attract public funds to the domestic stock market. It is known that the population of Russia invests in securities no more than $5 \%$ of their savings. The study of the pro-environmental behavior of investors in the Russian stock market seems to be very relevant and useful in line with the policy of the Bank of Russia in the financial market. In the "Guidelines for the Development of the Russian Financial Market in 2019 - 2021", it was noted that the rapid development of financial technologies, changing consumer demands, the growing cross-border nature of financial services, new approaches to regulation in the world create additional opportunities for the development of the domestic stock market [1]. The subject of the study is the pro-environmental awareness of investors in the stock market, which results in the formation of a new investment quality of green bonds. The aim of the study is to identify the factors and conditions of proenvironmental behavior of investors in the Russian stock market, ensuring the development of green financing mechanisms. Methodology. To study the pro-environmental behavior of investors in the Russian stock market, the main factors that influence the pro-environmental behavior of investors in the Russian stock market and the practice of disclosing non-financial statements by issuers of green bonds in the stock market are systematized. In substantiating the findings, comparative, economic and statistical methods of analysis were used.
\end{abstract}

\section{Introduction}

A scientific understanding of the underlying foundations of the functioning of the stock market as a multidimensional mechanism of overflow of savings into investments requires an analysis of the behavioral motives of its participants. It is generally accepted that an investor in the stock market is "in the gap between greed and fear". The relationship between "greed and fear" in investor strategies, models of his investment preferences for income and risk are studied by the theory of portfolio investment, anomalies in the psychology and behavior of investors in the market - the theory of behavioral finance. However, these theories do not affect new trends in the development of the stock market and the psychology of its participants. Without denying the need to develop traditional

\footnotetext{
*Corresponding author: vadimovna1231955@ mail.ru
} 
approaches to investment analysis as part of financial science, as well as to study behavioral motives in investors' actions, the authors of the paper offer to look at the tools and mechanisms of the stock market from a slightly different perspective: will environmental awareness, which was one of the reasons for the emergence and rapid development of the green bond market in international practice, lead to the emergence of a new segment of the domestic financial market, the change in the incentives in the construction of investment strategies of Russian citizens? If we consider the concept of environmental awareness as a combination of psychological factors that determine pro-environmental models of behavior, then the result of environmental awareness may be the emergence of a new behavioral effect - an investor's assessment of such investment quality of stock asset sold on the market as belonging to products of green investment, along with income, risk and liquidity. Now in Russia the market of green bonds is emerging, the foundations of green investment are being laid. In December last year, the first issue of green bonds of RSB KHMAO LLC was made.

\section{Materials and methods}

In traditional financial theory, the investor does not assess social, environmental and other qualities of the investment project financed by the purchase of securities. His preferences correspond to the economic model of rational choice and are limited to understanding the income and risk of the project. The financial market industry works in a similar way: investment analysis by a financial analyst is offered only in the context of a possible ratio of income and risk. As a result, the investor does not personally see "non-financial returns" from the investment made on the stock market. In addition, in practice, the investor is exposed to genetic memory associated with negative experience in investing in "financial pyramids", which has formed as a result of distrust of the state as a guarantor of honest behavior of professional participants in the financial market.

In our opinion, the totality of psychological factors of an individual, providing his predisposition to actively participate in pro-environmental models of behavior in the stock market, can testify to the emergence of environmental awareness. It is proposed to include among them:

a) the presence of "oversubscription" (the actual amount of the subscription to green bonds exceeds the originally planned size of their issue);

b) the rate of placement of green bonds in absolute terms (the number of hours since the official start of sales of green bonds) and relative value (compared with similar bonds of issuing credit quality);

c) the presence of stable groups of institutional investors involved in the acquisition of green bond issues;

d) an increase in the number of individual investors in absolute terms and relative value (compared with other purchasers of green investment instruments);

e) the emergence of specialized green funds established by major groups of institutional investors for investing in green bonds. These trends were observed when placing bonds of the largest issuers.

According to Bloomberg, over the past 10 years, the global market for environmental and social bonds has exceeded $\$ 430$ billion, with a third of all issued securities $(\$ 114$ billion worth of placement) only in 2018. The top 5 issuers in terms of placement in 2018 are presented in table 1. More than half of all placements in 2018 relate to the financial sector. In the regional context, China is the leader - it accounts for $28 \%$, or $\$ 32$ billion, of environmental and social bonds issued last year. Twice as little is accounted for by various international organizations (the same World Bank), which together occupy second place. Following are Germany, the Netherlands and the USA. The total volume of green bonds 
issued for the period from 2007 to 2018 is presented in table 2 [2]. In mid-2019, according to the Environmental Finance Bond Database, the volume of outstanding green bonds amounted to $\$ 657.9$ billion.

Table 1. Top 5 issuers in terms of placement of environmental and social bonds in 2018.

\begin{tabular}{|c|l|c|}
\hline No. & \multicolumn{1}{|c|}{ Issuer } & $\begin{array}{c}\text { Placed environmental and social } \\
\text { bonds, billion dollars for 2018 }\end{array}$ \\
\hline 1. & Industrial Bank of China & 9.6 \\
\hline 2. & European Investment Bank & 7.0 \\
\hline 3. & ING (Dutch financial group) & 4.3 \\
\hline 4. & The World Bank & 3.8 \\
\hline 5. & Industrial and Commercial Bank of China & 2.3 \\
\hline
\end{tabular}

Table 2. Issue of green bonds by region (cumulatively for 2007-2018).

\begin{tabular}{|l|c|c|c|}
\hline \multicolumn{1}{|c|}{ Region } & $\begin{array}{c}\text { Number of } \\
\text { countries }\end{array}$ & $\begin{array}{c}\text { Number of } \\
\text { issuers }\end{array}$ & $\begin{array}{c}\text { Volume of bonds issued } \\
\text { (billion dollars) }\end{array}$ \\
\hline Europe & 22 & 193 & 190 \\
\hline North America & 3 & 167 & 137 \\
\hline APR & 18 & 222 & 120 \\
\hline International organizations & - & 11 & 66 \\
\hline South America & 7 & 24 & 7 \\
\hline Africa & 4 & 11 & 2 \\
\hline
\end{tabular}

In order to study the behavioral (or psychological) parameters of pro-environmental behavior, it is proposed to study the incentives of investors to buy green bonds, for example, awareness of the importance of the transition to a low-carbon and climate-resilient economy.

The first step in the formation of pro-environmental behavior is the analysis of nonfinancial reporting by investors for the purpose of comprehensive disclosure of information about the company. The main purpose of the analysis of non-financial reporting is to ensure the transparency of the company, including its information activity. An analysis of nonfinancial reporting in which the company's performance is concentrated and issues of interest to key stakeholders, including investors (data on responsible business practices, activities in the field of corporate social responsibility and sustainable development are presented), are reflected should confirm the high ratings of green bonds and their low risks. The environmental awareness of investors is influenced by such factors as contribution to environmental protection and respect for human rights, quality of human resources management, quality of products and services, support for local communities, the company's impact on society in all key areas of its activity, compliance with ethical business principles, corporate governance quality, environmental issues of non-financial reporting.

The formation of pro-environmental behavior is based on increasing the transparency of economic activity. The World Business Council for Sustainable Development (WBCSD) has initiated the creation of a reporting information exchange mechanism - The Reporting Exchange global platform [3]. Nowadays, this platform unites more than 60 countries, providing coverage in more than 70 sectors of the economy, supporting the functioning of the mechanism of information transparency, rules for admission to quotes on exchanges, taking into account disclosure by issuers of the main parameters for issuing green bonds, 
including non-financial ones, which creates information base for the emergence of a wider circle of investors as a result of environmental awareness, the creation of additional demand in the stock market and the improvement of its situation.

The formation of environmental awareness in the stock market is objectively determined by global trends in the regulation of financial markets, specifically: in 2017, all EU countries introduced changes to national legislation in accordance with the requirements of the Non-Financial Reporting Directive of the Council of Europe (Directive 2014/95/EU) [4]. This year was the first reporting year for the mandatory disclosure of nonfinancial data in accordance with the Directive. The scope of this Directive covers large companies with an average number of employees over 500, they form the main pool of corporate bond issuers in the domestic stock market. According to the Directive, the nonfinancial report includes information related to the environmental and social aspects of the company's activities, as well as labor issues (concerning employees), respect for human rights, fight against corruption and bribery [13]. Regarding environmental issues, a nonfinancial report should contain detailed information on the current and projected environmental impacts of the enterprise and, if necessary, on health and safety, the use of renewable and/or non-renewable energy sources, greenhouse gas emissions, water use and air pollution. In support of the Non-financial Reporting Directive of the Council of Europe, a methodological document was published in 2017 - Recommendations of the European Commission on Non-Financial Reporting. In 2018, an updated version of the Exchange Guidance and Recommendations on Sustainability by The World Federation of Exchanges (WFE) was published. The document contains a set of indicators, including a number of new ones related to the financial assessment of climate risks, and recommendations for their reporting.

Although the Russian green investment market is still forming, the country has been practicing public non-financial reporting since 2000. The Russian State Standard GOST-R ISO 26000-2012 "Guidelines for social responsibility", which is in line with the main international and national documents in the field of sustainable development, social responsibility and public non-financial reporting, is aimed at creating a pro-environmental awareness in the Russian Federation. With regard to public non-financial reporting, this standard recommends that key topics of social responsibility and sustainable development, including governance, labor relations, environment, ethics, good business practices, anticorruption, respect for human rights and interaction with stakeholders, as well as contributions to the development of territories and local communities should be taken into account and reflected in the content of public non-financial reports.

Practical implementation of the new model of relations with investor within the framework of green finance bond programs in the stock market will require high transparency of the issuer's reporting on targeted spending of funds, a detailed risk map and their separation, etc., as well as an effective strategy for promoting financial products from professional participants of the securities market. This is not about traditional "bells and whistles" used in marketing the issue and circulation of securities, but about creating a new investment culture. Until the order of the Government of the Russian Federation "On Approving the Concept for the Development of Public Non-Financial Reporting and an Action Plan for its Implementation" was released in May 2017, non-financial reporting in Russia retained the status of a voluntary initiative, primarily of large business, which affected non-profit organizations and government institutions to a lesser extent. Adopting this regulatory document was the first step to create a regulatory framework for the formation of integrated reports in the Russian Federation. In accordance with this document, "the purpose of public non-financial reporting is to provide organizations with meaningful, complete, timely, accurate, balanced, comparable, reliable and objective information about their activities on economic, environmental, social aspects and 
management systems to meet information needs and requests of interested parties" [5]. According to the Concept, a number of companies will have to publish this information in 2019-2020. And by 2021-2022, over a thousand companies will be required to publish nonfinancial reporting. However, in December 2018, experts recorded the reluctance of most large Russian companies to publish non-financial statements. The authors of the corresponding study analyzed more than 1,400 companies and came to the conclusion about stagnation in the development of corporate transparency in Russia, with the emphasis that the group of leading companies formed in recent years has remained unchanged.

The current state of the Russian stock market is characterized by a lack of public awareness of the sold instruments (stocks and bonds) and investment opportunities in the stock market. The issue of reporting and information disclosure is no less acute. One of the reasons why companies are not ready to disclose is the presence of several types of reports that contain completely different performance indicators. Some companies compile a report on sustainable development, others - a social one, still others - an integrated one, and someone prefer to make an environmental report. Some of the data in them may intersect, but in general the sets of indicators turn out to be different. Processing reports of various structure and composition makes it impossible to quickly use these data for comparison and for the production of analytical products. The regulation of non-financial reporting indicators will allow using this information as a source of information for an independent assessment of companies' activities and drawing up indices and ratings of sustainable development and corporate social responsibility on its basis.

The domestic stock market as a whole is characterized by an insufficient level of public awareness of investment opportunities in the stock market, proposed products. Therefore, a significant part of the investment is "lost" for corporate financing. In our opinion, in the digital economy, there is the possibility of information support for the implementation of the project and according to the new philosophy of the stock market, not only in the numbers of financial statements according to certain rules, but also in an open information environment. To solve this problem, the Ministry of Economic Development of the Russian Federation developed a draft bill "On public non-financial reporting" and introduced it to the Government in July 2019. According to the bill, disclosing non-financial indicators of work in the field of sustainable development and social responsibility, issuers will be required to report on such environmental indicators as the amount of greenhouse gas emissions, the mass of pollutant emissions into the air, the amount of hazardous waste generated and disposed [12].

At the same time, many large Russian companies have been reporting non-financial statements for many years, publishing them in their own format, for example, combining annual reports with reports on sustainable development. Since 2006, a register of nonfinancial reports in the field of sustainable development, the National Register of Corporate Non-Financial Reports, has been maintained. It contains a register of companies publishing social, environmental, integrated, industry reports, reports on sustainable development, as well as a library of non-financial reports containing electronic versions of officially published non-financial reports of Russian companies and some large multinational companies. As of September 9, 2019, 178 companies were entered in the National Register of Non-Financial Reports, 972 reports were registered, which were issued in the period starting from 2000. Among them: 85 environmental and 328 social reports, 330 reports in the field of sustainable development, 202 integrated reports and 27 industry reports. Most of the companies listed in the National Register issue reports annually, which is in line with international practice. 


\section{Results}

The emergence of a new segment of the financial market as a result of the development of environmental awareness is possible, in our opinion, if the basis for the model of investor relations in the stock market is the concept of weakening the premise of rational investor behavior in financial decision-making only on the basis of the risk - return ratio without taking into account the investor's behavioral motives. The investment analysis of the stock instruments of the green financing class is based not only on the combination of traditional investment characteristics - profitability, risk, liquidity, but also on the analysis of changes in the quality of life of the company as a result of the implementation of the project financed by issuing securities on the basis of non-financial reporting analysis. The current state of the Russian stock market is characterized by a lack of public awareness of the sold instruments (stocks and bonds) and investment opportunities in the stock market. It has been proved that the main obstacle to expanding the investor base in the domestic stock market is the need to make significant efforts (for example, mental) with parties of a potential investor when making investments in securities in comparison with alternative sources of investments, as well as lack of a certain algorithm of actions of potential investors as a "role model". The draft Regulation "On Disclosure of Information by Issuers of Equity Securities" was also aimed at overcoming these shortcomings, which is expected to enter into force on January 1, 2020 [6]. The project reduces the administrative burden on issuers due to the presence in the current regulation of excessive disclosure requirements, including the amount of information disclosed by issuers in the securities prospectus, the issuer's report, and reports on material facts. At the same time, the Project concretizes certain provisions related to the disclosure of information in the event of the issue of green bonds.

The analysis of specific points of the Project related to the disclosure of information on the issue of green bonds showed that when they were formed, the Bank of Russia was guided by voluntary international standards, in particular, the Green Bond Principles (GBP) of the ICMA (International Capital Market Association). The draft reflects the recommendations of these Principles both with regard to the report on the use of borrowed funds and the report on the environmental impact of projects, as well as other recommendations for the disclosure of information.

In August 2019, the new version of the Moscow Exchange Listing Rules came into force, providing for the creation of the Sustainable Development Sector to finance projects in the field of ecology, environmental protection and socially significant initiatives. For inclusion of the Sustainable Development Sector in the green bonds segment, conditions have been introduced that indicate the first: the need for the issue, organization or investment project to comply with the principles (standards) in the field of green financing of the International Association of Capital Markets (ICMA) or the International Non-Profit Organization "Climate Bond Initiative (CBI)", including the existence of an independent external evaluation that is consistent with these principles. The second is that the conditions for the issuance of bonds and the prospectus of securities (if any) should provide for the targeted nature of the issue of bonds carried out to finance or refinance projects in the field of sustainable development. And the third condition is the issuer's commitment to disclose on the Internet page, provide one of the distributors of information on the securities market, and also submit to the Moscow Exchange for publication on the exchange website:

a) information on the decision of bodies or officials of state power, interdepartmental commissions or an independent external assessment;

b) a report (document) containing information on the proper (purposeful) use of the funds raised from the bond issue, including information on completed and planned stages of the implementation of projects throughout the entire term of the bonds' circulation. 
Thus, with the introduction of new conditions for the admission of green bonds to the Moscow Exchange, the Russian exchange market has established requirements (for inclusion in the listing) on the compliance of issued green bonds with international standards. The Moscow Exchange identifies several areas in which there may be funded projects for the placement of green bonds: renewable energy sources; increasing energy efficiency; pollution prevention; environmentally friendly transport; water and wastewater management; adaptation to climate change. Thus, in order to identify its bonds as green, the company must, with the help of an independent expert examination, prove that the project under which the money is taken meets internationally recognized standards of environmental financing. As of October 15, 2019, no issues of green bonds were included in the Sustainability Sector of the Moscow Exchange.

\section{Discussion}

The formation of the global green investment market is one of the main trends in the global stock market. Institutional investors with total managed assets of more than \$ 2 trillion, who are members of the Net-Zero Asset Owner Alliance, are planning to completely decarbonize their investment portfolios by 2050 [7]. They announced their intention to strengthen their work with the companies in which they invested in the transition to lowcarbon technologies and to reduce greenhouse gas emissions to zero by 2050 . According to a new HSBC poll (September 24, 2019), environmental and social issues are becoming increasingly important for issuers and investors to approach financing $[8,9]$. It is important to emphasize: the results are obtained from the HSBC survey on sustainable financing and investing in 2019, a survey of 500 investors and 500 issuers from the countries of America, Asia, Europe and the Middle East. The survey results fully confirm the conclusions of the authors of this paper.

More than $90 \%$ of global investors and corporate debt issuers say that these factors are important or very important in their thinking, $60 \%$ of investors say that there are obstacles preventing them from investing sustainably, including a lack of experience and comparable data on the environment, social sphere and management (Environmental, Social and Governance, ESG) for various investments and lack of suitable investment opportunities. Publications confirm the emergence of a global trend - the emergence of a new segment of the financial market as a result of the development of environmental awareness. Nowadays, the Russian Union of Industrialists and Entrepreneurs (RUIE) has published 6 analytical reviews in the field of non-financial reporting, reflecting its formation and development in international and Russian practice. In 2006, the first non-financial reporting analytical review was published. It was the first to analyze the situation with non-financial reporting in Russia, the "basic level" was recorded, relative to which the progress is measured in this area. RUIE publishes such reviews on an ongoing basis with a frequency of once every two years. The last such document was released for the period of 2017-2018 and includes a study of trends in the development of non-financial reporting in the world in the context of sustainable development, statistics of non-financial reporting in Russia and the world, and the results of Russian business practices in the reporting context [10-14].

\section{Conclusions}

Creating a market for green financing tools that are used for environmental projects related to energy conservation and improving the quality of life of a society requires the development of environmental self-awareness of investors. The main factor shaping the pro-environmental behavior of investors is the formation of an adequate information 
environment that ensures the disclosure of information when issuing green bonds in the context of international requirements. A prerequisite for the pro-environmental behavior of investors in the Russian stock market is the availability of appropriate infrastructure. Since August 12, 2019, the Sustainable Development Sector, the first full-fledged platform for supporting environmental projects on the Russian financial market, has been launched on the Moscow Exchange. So far, no circulating instruments have been presented in this Sector, but with the development of the environmental awareness of investors, bonds of Russian and foreign organizations should appear, the income from the placement of which will go to programs significant for nature and society.

\section{References}

1. The main areas of development of the financial market of the Russian Federation for the period of 2019-2021, https://cbr.ru/content/document/file/71220/main_directions.pdf

2. Green Bonds: State of the Market, 5 (2018) https://www.bonddata.org/

3. Global Resource for Sustainability Reporting, https://www.reportingexchange.com/

4. Directive 2014/95/Eu Of European Parliament And Council Of October 22, Official Journal of the European Union (2014) https://eur-lex.europa.eu/eli/dir/2014/95/oj

5. Decree of the Government of the Russian Federation of May 5, 2017 No. 876-r, https://www.garant.ru/products/ipo/prime/doc/71573686/

6. Draft bill of the Bank of Russia "On Disclosure of Information by Issuers of Equity Securities", http:/www.consultant.ru/cons/cgi/online.cgi?req=doc;base=PNPA;n= 49681\#043487387767887176

7. Asset owners plan to completely decarbonize their investment portfolios by 2050, https://investinfra.ru/mezhdunarodnaya-praktika/vladelcy-aktivov-planiruyutpolnostyu-dekarbonizirovat-svoi-investicionnye-portfeli-k-2050-godu.html

8. HSBC Sustainable Financing and Investing Survey 2019: Markets alert to the environment and society, https://www.hsbc.com/news-and-insight/2019/sustainableinvesting-takes-centre-stage

9. A.V. Bataev, A.A. Gorovoy, A.B. Mottaeva, Proceedings of the 32nd International Business Information Management Association Conference, IBIMA 2018 - Vision 2020, 88-101 (2018)

10. E.N. Feoktistova, L.V. Alenicheva, G.A. Kopylova, M.N. Ozeryanskaya, D.R. Purtova, N.V. Khonyakova, Analytical review of corporate non-financial reports for 2017-2018 (RUIE, Moscow, 2019) http://media.rspp.ru/document/1/f/6/f6e6f97287df39e326d6b2d236b459b1.pdf

11. E.V. Semenkova, L.N. Andrianova, K.V. Krinichansky, Journal of Reviews on Global Economics 7, 562-571 (2018)

12. E.V. Semenkova, L.N. Andrianova, Financial business 5, 13-24 (2018)

13. G. Semenova, E3S Web of Conferences TPACEE-2018 91, 08047 (2019) https://doi.org/10.1051/e3sconf/20199108047

14. G. Semenova, E3S Web of Conferences, TPACEE-2018 91, 08046 (2019) https://doi.org/10.1051/e3sconf/20199108046 